\title{
Musical life in Belgrade as an instrument of global political polarization on the eve of WWII
}

\author{
Ranka Gašić
}

International relations in the 1930s were characterized by disintegration of the international order established at the Versailles Peace Conference, which marked the end of WWI. The political rupture between the Third Reich on one side and the socalled Western democracies (Great Britain and France) on the other was escalating rapidly. The Yugoslav government was striving to uphold its position of neutrality. However, the international context - the country's relations to the war allies (Britain and France) and its membership in the Little Entente (a defensive alliance between Yugoslavia, Romania and Czechoslovakia) — did have a significant impact on social and cultural life in the country. The dominant cultural models were coming from Western and Central Europe. German culture exercised an influence for a long time. In the $19^{\text {th }}$ century, it was Austrian culture that left a significant mark on the Serbian society, and the German cultural contents and models continued even after the bitter experience of WWI. However, political use of culture in this respect was appearing gradually and reached its peak at the time when WWII broke out in 1939. Cultural influences in Yugoslavia took a turn in 1934, when the assassination of Yugoslav King Alexander I in France ended the era of French-dominated influence, which was then supplanted by the British one. By the eve of WWII, the cultural life in Belgrade had become a theater of fierce competition between the Third Reich and Great Britain.

Music was perhaps the least developed form of art in interwar Belgrade. Before WWI, musical life in Belgrade was shaped by choral societies and a small number of music schools. Most music institutions were founded only after 1918the Belgrade Philharmonic in 1923, the South Slav Choral Union in 1924, the Collegium Musicum in 1926, and the Music Academy as late as 1937. Therefore, in the case of 1930s Belgrade, music was perhaps the least suitable means of cultural and political propaganda. However, the developments in international politics did in fact have an impact on the musical life in Belgrade, due to the activities of several associations dealing with cultural propaganda: the German Academy in Munich, the British Council in London, and the bilateral societies in Belgrade dealing with the implementation of the cultural policies formulated abroad and with organizing cultural events. From 1939 on, when a propaganda, economic 
and intelligence warfare between the Third Reich and Britain was underway in Belgrade, both countries established their institutes for general coordination of cultural propaganda activities. In the case of Germany, this was done by direct contact between state representatives (press attaché of the Yugoslav Embassy in Berlin and the president of the German Academy), whereas the British Council collaborated closely with the Anglophile societies in the country. ${ }^{1}$

In the two interwar decades, the German cultural influence underwent a great change. In 1921, Vienna-based pianist Moriz Rosenthal encountered a very unwelcoming treatment from the Belgrade audience, which demonstrated openly the hostility toward his homeland, and violinist Sigmund Feuermann played in front of an almost empty concert hall. ${ }^{2}$ However, the same year (1921), certain intellectual circles began working toward the renewal of cultural relations between Germany (then Weimar Republic) and Serbia (then Kingdom of Serbs, Croats and Slovenes). The German-Yugoslav Society was established in Frankfurt am Main, under the leadership of politician and historian Herman Wendel. ${ }^{3}$ It engaged in various cultural activities, including musical soirees. ${ }^{4}$ In 1930, a similar Yugoslav-German Society was established in Belgrade, which also undertook the organizing of "music shows." ${ }^{5}$ However, in the late 1930s, all Yugoslav-German Societies were subordinated to the German Ministry of Foreign Affairs. To that end, a German Scientific Institute was set up in 1940. Cultural activities instigated by the German cultural propaganda institutions were held across the country, always including German settlements in Vojvodina. Rikard Švarc, a renowned Belgrade music critic, in his otherwise very affirmative review of the concerts by the Magdeburg Madrigal Singers in Belgrade and several towns in Vojvodina in the autumn of 1935 nevertheless commented on the propaganda character. ${ }^{6}$

\footnotetext{
1 See Ranka Gašić, Beograd u hodu ka Evropi. Kulturni uticaji Britanije i Nemačke na beogradsku elitu 1918-1941 [Belgrade on the Way to Europe: Cultural Influences of Britain and Germany on the Belgrade Elite 1918-1941] (Belgrade: Institut za savremenu istoriju, 2005); Ranka Gašić, "Srpska kultura između dva svetska rata [Serbian culture between the two World Wars]," Istorija 20. veka 2 (2008): 162-182.

2 Radina Vučetić-Mladenović, Evropa na Kalemegdanu: "Cvijeta Zuzorić” i kulturni život Beograda 1918-1941 [Europe in Kalemegdan. "Cvijeta Zuzorić" and the Belgrade Cultural Life 1918-1941] (Belgrade: Institut za noviju istoriju Srbije, 2003), 99-100; Stanislav Vinaver, "Muzički život [Musical life]," Misao VI/56 (1921): 416.

3 The Political Archive of the Federal Foreign Office [Politisches Arhiv des Auswaertigen Amtes (PA-AA)] Bonn, Cultural-Political Department [Kultur-Politische Abteilung (Kult-Pol)] VI W R 65793, Statute of the Yugoslav-German Society, 4; PA-AA, Bonn, Kult-Pol VI W R 65793, The correspondence of the German Foreign Ministry from 1929, 1930 and 1931.

4 PA-AA, Bonn, Kult-Pol VI W R 65793, Statute ..., 2.

5 PA-AA, Bonn, Kult-Pol VI W R 65798, Annual report of the Yugoslav-German Society's Board for the 1932/1933, Annual report ... 33/34; Annual report ... 1938.

6 Rikard Švarc, "Muzika u zemlji [Music around the country]," Zvuk 8-9 (1935): 319. On the work of Rikard Švarc, see Aleksandar Vasić, "Muzički kritičar Rikard Švarc [Rikard Švarc, the music critic]," Zbornik Matice srpske za scenske umetnosti i muziku 61 (2019): 87-103.
} 
It was not until the late 1930s that more important guest performances by German musicians took place-those of the Frankfurt Opera (1938), the Dresden String Quartet (1940), the Munich String Trio (1940), the Berlin Philharmonic Chamber Orchestra and the Vienna Boys' Choir (between 1937 and 1940). ${ }^{7}$ As the war was approaching, the Yugoslav authorities were trying not to align the country too closely with the Third Reich and consequently jeopardize its neutrality. So Radio Belgrade and the Belgrade Music Academy took part in organizing the Munich String Trio's performances in late 1940, together with the German Scientific Institute, while on the other hand, the Yugoslav Ministries of Foreign and Internal Affairs expressed their disapproval with the organizing of the Dresden String Quartet's concerts in the spring of 1940 "in view of the political situation." Although the ministries did not officially ban the concerts, they kept track of the people who attended them. ${ }^{8}$

The guest performances of the Frankfurt Opera in 1938 were a major event for Belgrade at the time. Several of its members were awarded with high Yugoslav decorations. ${ }^{9}$ On that occasion, Pavle Stefanović, a prominent music critic, published in Glasnik Muzičkog društva "Stanković" (Stanković Music Society Herald) two very positive reviews of their performances of Le nozze di Figaro (The Marriage of Figaro), Der Rosenkavalier (The Rose-Bearer) and Die Walküre (The Valkyrie). These reviews were, however, accompanied with a commentary on the international political context. Relating to "the motives of cultural and political propaganda of the extremely expensive and massive undertaking of the Third Reich's Frankfurt Opera, which, by venturing an excursion to the cultural centers of Romania and Yugoslavia, virtually degraded itself," Stefanović writes about mass emigration of Jewish and other politically unsuitable musicians from the Third Reich, the country where "Hindemith was silenced." He believed that this musical event was an attempt to "atone for the bad impressions made on the international community by the abominable treatment of art in that country."

The persecution of Jewish musicians in the Third Reich also left its mark on the Belgrade musical life. The Hanigun Jewish Choral Society, composed of Jewish opera singers who fled Germany held three concerts in Belgrade in 1934, performing Jewish sacred and folk music. ${ }^{10}$ German opera director and conductor of Jewish origin Erich Hetzel (1899-1944) studied drama, music and literature, and

\footnotetext{
7 Archives of Yugoslavia [Arhiv Jugoslavije (AJ)], Ministarstvo prosvete Kraljevine Jugoslavije [Ministry of Education of the Kingdom of Yugoslavia], 66-454-718, Report on the activities of the Department for International Cultural Relations.

8 AJ, 66-374-610, Letter of the Minister of the Interior to the Ministry of Education, March 22, 1940.

9 AJ, 66-344-582, Ministry of Education enactment, May 1938.

10 Rikard Švarc, "Muzika u zemlji. Beograd. (Orguljski koncert Jurija Arbatskog. Amaterski orkestar Lira. Jevrejsko vokalno udruženje Hanigun. Glasbena matica iz Ljubljane) [Music around the
} 
worked in various German theaters before emigrating to Belgrade in 1933. He was employed by the Opera of the Belgrade National Theater in 1934 as professional opera director. He was a representative of the German modern-style opera direction. While in Belgrade, he had the opportunity to stage ten operas of very different styles-from the $18^{\text {th }}$ century to the modern-day operas by Richard Strauss and Dmitri Shostakovich. His stagings of Wagner's operas in Belgrade were based on the latest versions from the Bayreuth Festival and Wieland Wagner's innovations. He directed several of the most successful opera performances in Belgrade on the eve of WWII-The Merry Wives of Windsor, Gianni Schicchi, Tannhauser and Don Quixote. ${ }^{11}$ During the Nazi occupation of Belgrade (1941-1944) he was in hiding, only to be killed in the Allied bombing of Belgrade in April 1944. ${ }^{12}$ Another opera director of Jewish origin was Joseph Krisp (1902-1974) from Austria, director of the Vienna State Opera and the Vienna Philharmonic Orchestra who fled to Belgrade in 1938, after the Anschluss. He was engaged as a guest director at the Opera of the Belgrade National Theater for the 1938/39 season. There he conducted Mozart's Le nozze di Figaro and Die Zauberflöte (The Magic Flute), Verdi's Un Ballo in Maschera (A Masked Ball), La Traviata, Aida, Il Trovatore (The Troubadour), Puccini's Madama Butterfly, Rossini's Il barbiere di Siviglia (The Barber of Seville), Smetana's Prodaná nevěsta (The Bartered Bride), and Mussorgsky’s Boris Godunov. He was later praised by music critics for his significant contribution to the overall professional level of the Belgrade Opera. ${ }^{13}$

The opposition of Belgrade intellectual circles to the government's Germanophile policy was also plainly demonstrated in the case of the Obilić Academic Choral Society's tour to Germany, which was planned for 1936 and was canceled at short notice. In his report to the German Foreign Ministry, German Ambassador to Yugoslavia Victor von Heeren referred to "Francophile university

country. Belgrade. (Organ concert by Yury Arbatsky. The Lira amateur orchestra. The Hanigun Jewish Vocal Society. Musical society Glasbena matica of Ljubljana]," Zvuk 6 (1934): 233-234.

${ }^{11}$ Stana Đurić-Klajn, "Muzički život u Beogradu između dva rata [Musical life in Belgrade between the two world wars]," in Istorija Beograda III, edited by Vasa Čubrilović (Belgrade: SANU, Prosveta, 1974), 398-409, 402.

12 Aleksandar Radovanović, Pregled istorije Narodnog pozorišta u Beogradu 1868-1993 [Overview of the history of the National Theater in Belgrade, 1868-1993] (Belgrade: Narodno pozorište, Institut za književnost i umetnost, 1994), 70, 82; Roksanda Pejović, Opera i balet Narodnog pozorišta u Beogradu (1882-1941), (Belgrade, 1996), 119-121, 241-244; Nadežda Mosusova, "Srpska muzička scena (125 godina Narodnog pozorišta) [Serbian musical scene (125 $5^{\text {th }}$ anniversary of the National Theater)]," Srpska muzička scena. Zbornik radova sa naučnog skupa održanog od 15. do 18. decembra 1993. godine povodom 12-godišnjice Narodnog pozorišta, edited by Ana Matović, Nadežda Mosusova, Ranko Ivančević (Belgrade: Muzikološki institut SANU, 1995), 5-37, 25.

${ }^{13}$ Pejović, Opera i balet, 235, 255-256; Raško Jovanović, Olga Milanović, Zoran Jovanović, 125 godina Narodnog pozorišta u Beogradu [125 th anniversary of the National Theater in Belgrade] (Belgrade: SANU, 1994), 203; Aleksandar Radovanović, Pregled istorije Narodnog pozorišta, 79. 
professors," particularly historian Vladimir Ćorović, and "their influence on members of the Choral Society," recommending, at the same time, that another attempt be made to organize the canceled Obilić tour. ${ }^{14}$ However, it was not Corović, but Branko Dragutinović, the conductor of the Choral Society at the time, who instigated this short notice cancelation. He became a freemason the same year. As a correspondent for masonic magazines Javnost and Vidici, he frequently published articles on the oppression of Jewish and other artists in the Third Reich. ${ }^{15}$

Musicians from Belgrade took part in three international competitions in Vienna (in 1933 and 1937) by invitation of the Austrian Embassy, the University of Music and Performing Arts and distinguished Vienna musicians. In 1933, Belgradebased composers Petar Krstić and Josip Štolcer Slavenski were members of the jury at the international piano and singing competition in Vienna. Yugoslav participants were very successful in this competition, and Vienna State Opera director Klemens Kraus was awarded a high Yugoslav decoration on this occasion. ${ }^{16}$ At the time of the most intensive state-sponsored international cultural activity (1937-1940), there were only three guest performances of Belgrade musicians in Germany: the Opera of the Belgrade National Theater, the Ballet of the Belgrade National Theater, and the private ballet company_Students' Folk Company_led by Maga Magazinović at the Hamburg Folk Festival in July 1939. ${ }^{17}$ Yugoslav authorities insisted on the principle of equal quality of guest performances in terms of musicians' skills and reputation, which was almost impossible in the case of two so very different cultural and social milieus. A guest performance of an operetta company from Vienna was declined by the Ministry of Education in June 1939, for being "below the artistic level that was

\footnotetext{
${ }^{14}$ AJ, The Central Press Agency [Centralni Presbiro], 38-49-108, Report of the Agency's correspondent M. Crnjanski for the first half of 1937; PA-AA, Bonn, Kent III, Political Department [Politische Abteilung] IV, 103320, 001, Ambassador von Heeren to the German Ministry of Foreign Affairs, May 14, 1936.

${ }^{15}$ Music critic Branko M. Dragutinović (Belgrade, 1903-1971) attended a music school in Belgrade and studied music history at the Belgrade University. His professor was Miloje Milojević, a distinguished Serbian composer. From 1925 to 1938, he was the conductor of the Obilić Academic Choral Society. He worked as secretary of the Belgrade Opera from 1938 to 1940, and as a high school lecturer until 1944. After 1945 he taught at the Belgrade Music Academy, and worked as an assistant director of the Opera from 1950. He was continuously active as a music critic from 1926 on, and published articles in different Belgrade-based journals and magazines. ("Branko Dragutinović," Leksikon jugoslavenske muzike I (Zagreb: JLZ Miroslav Krleža, 1984), 203-204.) He became a member of the Dositej Obradović Masonic Lodge in 1936. See Zoran D. Nenezić, Masoni u Jugoslaviji 1764-1980 [Freemasons in Yugoslavia, 1764-1980] (Belgrade: Narodna knjiga, 1984), 573.

16 AJ, 66-374-610, Ministry of Education enactment, 1933.

17 AJ, 66-454-718, Report of the Department for International Cultural Relations; AJ, 38-141-414, Press articles on the Maga Magazinović German Tour; Gojko Miletić, "Međunarodna afirmacija Narodnog pozorišta [International affirmation of the National Theater]," in Jedan vek Narodnog pozorišta u Beogradu 1868-1968, edited by Milan Đoković (Belgrade: Narodno pozorište, Nolit, 1968), 554-571.
} 
agreed upon" between Yugoslav and German ministries. Since the Belgrade Opera had already performed in Frankfurt, a private operetta company was considered to be below that artistic level. ${ }^{18}$ Many prominent opera singers from Belgrade performed in Germany at the time, such as Zlata Đunđenac, Anita Mezetova, Janja Vasiljeva, Krsta Ilić and Vladeta Popović. Melanija Bugarinović was one of the few who took part in Wieland Wagner's Bayreuth Festival. Bahrija Nuri Hadžić also had a very successful career in German-speaking countries, performing in Vienna in 1934 and 1938, and in Zurich in 1939. ${ }^{19}$

On the other hand, the most influential factors of the British cultural propaganda were Anglophile associations and Radio Belgrade.

The large number of Anglophile intellectuals and activists in Belgrade was organized into three bilateral societies: the Anglo-American-Yugoslav Club (established in 1924), the Society of Friends of Great Britain and America (1930), the Society for Promoting Anglo-Saxon Culture in Yugoslavia (1935), as well as two more associations dealing with cultural relations with Britain (the Society of Former British Students, and the Society of Students of English Language and Literature). ${ }^{20}$ After June 1940, all Anglophile activities were coordinated by the Yugoslav British Institute.

Local musicians had long since been familiar with German and generally Central European cultural centers and music. This was, however, not the case with Britain and Anglo-American culture. English music was almost completely unknown to the Belgrade audience. Although performances by British (and even more so American) musicians were rare after WWI, their frequency rose significantly precisely in the late 1930s. British and American musicians held several concerts in Belgrade, organized by the Anglophile societies, starting from 1929. In December 1929, British pianist Frederic Lamond performed at the Stanković Music School Hall, and in the following year Utica Jubilee Singers from the US gave a concert at Hotel Kasina. Also in 1930, the efforts of composer Kosta Manojlović, a former British student, in his capacity as the Secretary General of the South Slav Choral Union, made is possible to organize a tour of an orchestra composed of fifty British musicians throughout Yugoslavia. ${ }^{21}$ In December 1933, the Society of Friends of Great Britain and America, together with the Belgrade branch of the

\footnotetext{
18 AJ, 66-454-718, Report of the Department for International Cultural Relations, June 15, 1939. ${ }^{19}$ AJ, 66-454-718, Report of the Department for International Cultural Relations, 1934, 1938, 1939; Jovanović, Milanović, Jovanović, 125 godina Narodnog pozorišta, 221; Mirka Pavlović, "Veličina iz Beograda - Bahrija Nuri Hadžić (1904-1993) [A star from Belgrade-Bahrija Nuri Hadžić (1904-1993)]," in 125 godina Narodnog pozorišta u Beogradu. Zbornik radova sa naučnog skupa održanog 16-19. novembra 1994, edited by Stanojlo Rajičić (Belgrade: SANU, 1997), 417-437.

${ }^{20}$ Milan Milojević, Anglo-Yugoslav Cultural Relations (London: s.n., 1944), 7, 11.

${ }^{21}$ AJ, 66-374-610, Concert of the Utica Jubilee Singers from the USA; AJ, 38-73-197, The guest performance of English Musicians' Group in August 1930, September 1930; Esther Johnson's petition, AJ, 66-374-610, October 1933.
} 
YMCA, organized a concert of the First Belgrade Choral Society at an English Evening, followed by a Shakespeare recital. ${ }^{22}$ In order to further promote AngloSaxon culture, the Anglophile societies organized an English Week in Belgrade (October 1934), which closed with an English Musical Evening. ${ }^{23}$ The Mokranjac Choral Society always took part in annual celebrations of the "Anglo-American Day" (i.e. Armistice Day, November 11) from 1935 on. ${ }^{24}$

All the guest performances by both British and American musicians in the late 1930s were organized by the British Council in collaboration with the Society of Friends of Great Britain and America. One of them was Esther Johnson's concert in October 1938, when the American pianist played contemporary Yugoslav art music among other pieces. Both British and American musicians expressed their interest in Yugoslav folk music. Hugh Ross, a British-born American conductor of the Schola Cantorum of New York, consulted the Yugoslav authorities in 1938 for the purpose of selecting Yugoslav folk songs and dances to be presented at the World Exhibition in New York. ${ }^{25}$ A few years earlier, in 1932, British folk song collector Julia Chatterton came to Yugoslavia in search of material for her folk music anthology. ${ }^{26}$

British musicians performed mostly English, both art and folk music in Belgrade. In February 1937, the Fleet Street Choir performed a set of English songs at the Kolarac University and the Manjež Theater, and bass-baritone singer Keith Falkner gave a concert of modern English serious music together with pianist Cyril Smith. In 1939, English folk singer Ethel Lewis gave two recitals at the Anglo-Yugoslav Club and the Music Academy, which were broadcast by Radio Belgrade. ${ }^{27}$ On the very eve of WWII, in May 1939, the US Ambassador to Belgrade gave an introductory speech on Yugoslav-American relations, opening a concert of American modern music in Belgrade. The performers were American musicians accompanied by the Radio Belgrade Symphony Orchestra. 28

\footnotetext{
22 "An English Evening," South Slav Herald (December 1, 1933): 5.

23 "An English Week," SSH (October 3, 1934): 1.

24 “An English Week," SSH (May 16, 1934): 1; “An English Week," SSH (October 3, 1934): 1; "Armistice Day 1935," SSH. (November 16, 1935): 1; "Armistice Day in Belgrade," SSH (November 16-30, 1936): 2.

${ }^{25}$ AJ, 66-374-610, Letter of the Yugoslav Consul General in New York, B. P. Stojanović, to the Ministry of Education, August 1938.

26 "English Composer in Belgrade," SSH (May 17, 1932): 1.

27 "Sir Hamilton Harty," SSH (November 1-16, 1936): 2; "Music-Art-Theatre in Yugoslavia," SSH (February 18-28, 1935): 5; "Belgrade Calling," SSH (February 1-16, 1937): 2; "Belgrade Calling," SSH (October 1, 1938): 1; "Ester Johnson's Concert," SSH (December 16, 1932): 2; AJ, 38-73-197, Bulletin of the Anglo-American-Yugoslav Club, January 1939; AJ, 38-73-197, Bulletin of the AngloAmerican-Yugoslav Club, January and February 1940.

28 AJ, The collection of the Society of Friends of Great Britain and America [Udruženje prijatelja Velike Britanije i Amerike u Jugoslaviji] (342), Report of the Society's Board, May 31, 1939.
} 
Radio was a modern cultural propaganda medium which few citizens of Yugoslavia could afford in that time. On July 15, 1924 a Radio Club was founded in Belgrade. Its members were mostly young people from the upper middle class, state officials, academics, university professors, engineers and doctors. These amateur radio enthusiasts helped the process of widening the radio network and increasing the number of then very expensive radio sets. The radio subscription rate in Yugoslavia was the lowest in Europe (only 0.3\% in 1933). ${ }^{29}$ With a total of 100,000 radio sets in Yugoslavia on the eve of WWII, radio was accessible only to the upper middle class. ${ }^{30}$ Radio Belgrade was established as a joint-stock company in March 1927. It was granted a concession for fifteen years, so in August 1940 the company was taken over by the state. The majority stockholder was Julius Hanau, a representative of the Marconi Wireless Co., incidentally also a high-profile British intelligence agent. Radio Belgrade Inc. is a very good example of global political polarization in terms of capital investment and cultural propaganda. As a new and expensive medium, Radio Belgrade was financed and technically equipped exclusively by foreign capital. For example, in April 1933, 98\% of the shares were owned by British citizens. ${ }^{31}$

In the years just before WWII, editors at Radio Belgrade were connected in different ways with either Anglophile circles or with the official government policy toward the Third Reich. This also reflected in the music programing of Radio Belgrade. There were many broadcasts of musical events in Austria and Germany, like the Salzburg Music Festival or the Bayreuth Festival. The Salzburg Music Festival was regularly broadcast. The opera radio program was very versatile: it covered a wide range from Gluck's Orpheus to R. Strauss' Salome and Shostakovich's Katerina Izmaylova. The first edition of the Great Opera Evening series was broadcast on June 2, 1929, featuring Wagner's operas performed by the Belgrade National Theater Opera. From 1935, the Radio Belgrade Orchestra performed operas and symphonic concerts in the studio. ${ }^{32}$

The concerts by English and American musicians in Belgrade were often broadcast by the Radio. When the British cultural propaganda in Yugoslavia intensified in 1937, the Radio Belgrade's board of directors was changed, and Mihailo Vukdragović was appointed conductor and music director of the Radio

\footnotetext{
29 "Special Radio Features in This Issue," SSH (November 1, 1933): 1.

${ }^{30}$ Radivoje Marković, "Prve godine [The first years]," in Ovde Radio Beograd. Zbornik povodom pedesetogodišnjice, edited by Milan Bulatović et al. (Belgrade: Radio Beograd, 1979), 11-29; Milan Bulatović, "Do celovitog sistema pet programa [Before the system of five programs was built]," in Ovde Radio Beograd, 37-51.

${ }^{31}$ Marković, "Prve godine," 13-14.

${ }^{32}$ Ljubomir Kocić, Ljubinko Miljković, “Tragovima sazvučja muzike [Following the musical harmonies]," in Ovde Radio Beograd. Zbornik povodom pedesetogodišnjice, edited by Milan Bulatović et al. (Belgrade: Radio Beograd, 1979), 103-129.
} 
Belgrade Orchestra. As an antifascist and a freemason, he-together with Vojislav Vučković-left a significant mark on Radio Belgrade's musical program. Armistice Day celebrations were also regularly broadcast. On March 31, 1938, the Radio Belgrade Symphony Orchestra, conducted by Vukdragović, gave a concert of modern American music, organized by the Society of Friends of Great Britain and America, and the National Federation of Music from North Dakota (US). Vukdragović took this opportunity to acquire written music of modern American composers to be performed in Belgrade in the autumn of 1938. ${ }^{33}$

By 1940, Yugoslavia was already forced into the political sphere of the Third Reich. After that, the shares of Radio Belgrade Inc. were taken over by the state, which consequently led to a replacement of its music director. Kosta Manojlović was now appointed to the post, together with Stevan Hristić and Svetomir Nastasijević. ${ }^{34}$ Radio Belgrade now broadcast more music performances by German musicians, such as the one by the Berlin Philharmonic Chamber Trio on May 19, 1940. After that, out of the total of 46 music radio broadcasts of foreign musicians' performances, 15 were German, 13 Hungarian and none were English. Radio Belgrade not only broadcast, but also organized concerts of German musicians-like the one by Maria Nemet, a soloist of the Vienna State Opera on January 3, 1941. ${ }^{35}$

The position of Yugoslavia in international relations in the 1930s and the global political rupture took their toll on the musical life in Belgrade. On the one hand, propaganda activities were also engineered in the centers of political power abroad-such as propaganda tours of German musicians in Belgrade but also in Vojvodina, as well as the efforts of the British Council to organize concerts of British and also American musicians. Also important was the attitude of the Belgrade audience and the creators of cultural policies toward the political developments in Europe, such as the persecution of Jewish artists in the Third Reich. This attitude was clearly manifested in the acts of welcoming Jewish musicians, canceling Obilic's German tour, intensive Anglophile activities in the late 1930s, cooperation with English and American performers, and finally, the musical radio program as a reflection of the competing foreign capital and the Yugoslav government's delicate handling of international relations in the 1930s.

\footnotetext{
33 AJ-342, Report to the Society's Annual Assembly, May 1938.

${ }^{34}$ Kocić, Miljković, “Tragovima sazvučja muzike," 111. Hristić was a grandson of the $19^{\text {th }}$-century politician Nikola Hristić. He studied in Leipzig and other places in Germany, and later worked as a professor at the Belgrade Music Academy. See Nadežda Mosusova, "Mesto Stevana Hristića u jugoslovenskoj i evropskoj muzici [Stevan Hristić in the context of Yugoslav and European music]," in Život i delo Stevana Hristića: zbornik radova sa naučnog skupa održanog 19. i 20. novembra 1985. povodom 100-godišnjice kompozitorovog rođenja, edited by Dimitrije Stefanović (Belgrade: SANU, 1991), 1-7. ${ }^{35}$ AJ, 66-374-610, Report on the Radio Belgrade program to the Ministry of Education.
} 


\section{Primary sources:}

Archival sources

Archives of Yugoslavia (AJ) (Belgrade): Ministry of Education of the Kingdom of Yugoslavia; Central Press Agency; Society of Friends of Great Britain and America

The Political Archive of the Federal Foreign Office (PA-AA) (Bonn/Berlin): Cultural-Political Department; Kent III, Political Department IV
Press and Periodicals

South Slav Herald, Belgrade, 1932-1941

Zvuk, Belgrade, 1932-1936

\section{References::}

"Branko Dragutinović." Leksikon jugoslavenske muzike I. Zagreb: JLZ Miroslav Krleža, 1984, 203-204.

Bulatović, Milan. "Do celovitog sistema pet programa." In Ovde Radio Beograd. Zbornik povodom pedesetogodišnjice, edited by Milan Bulatović et al., 37-51. Belgrade: Radio Beograd, 1979. [Orig. in Serbian Cyrillic]

Đurić-Klajn, Stana. "Muzički život u Beogradu između dva rata. In Istorija Beograda III, edited by Vasa Čubrilović, 398-409. Belgrade: SANU, Prosveta, 1974. [Orig. in Serbian Cyrillic]

Gašić, Ranka. Beograd u hodu ka Evropi. Kulturni uticaji Britanije i Nemačke na beogradsku elitu 1918-1941. Belgrade: Institut za savremenu istoriju, 2005.

Gašić, Ranka. "Srpska kultura između dva svetska rata," Istorija 20. veka 2 (2008): 162-182. [Orig. in Serbian Cyrillic]

Jovanović, Raško, Milanović, Olga, Jovanović, Zoran. 125 godina Narodnog pozorišta u Beogradu. Belgrade: SANU, 1994. [Orig. in Serbian Cyrillic]

Kocić, Ljubomir, Miljković, Ljubinko. “Tragovima sazvučja muzike." In Ovde Radio Beograd. Zbornik povodom pedesetogodišnjice, edited by Milan Bulatović et al., 103-129. Belgrade: Radio Beograd, 1979. [Orig. in Serbian Cyrillic]

Marković, Radivoje. "Prve godine.” In Ovde Radio Beograd. Zbornik povodom pedesetogodišnjice, edited by Milan Bulatović et al., 11-29. Belgrade: Radio Beograd, 1979. [Orig. in Serbian Cyrillic]

Miletić, Gojko. "Međunarodna afirmacija Narodnog pozorišta." In Jedan vek Narodnog pozorišta u Beogradu 1868-1968, edited by Milan Đoković, 554-571. Belgrade: Narodno pozorište, Nolit, 1968. [Orig. in Serbian Cyrillic]

Milojević, Milan. Anglo-Yugoslav Cultural Relations. London: s.n, 1944.

Mosusova, Nadežda. "Mesto Stevana Hristića u jugoslovenskoj i evropskoj muzici." In Život $i$ delo Stevana Hristića: zbornik radova sa naučnog skupa održanog 19. i 20. novembra 1985. povodom 100-godišnjice kompozitorovog rođenja, edited by Dimitrije Stefanović, 1-7. Belgrade: SANU, 1991. [Orig. in Serbian Cyrillic]

Mosusova, Nadežda. "Srpska muzička scena (125 godina Narodnog pozorišta)." In Srpska muzička scena. Zbornik radova sa naučnog skupa održanog od 15. do 18. decembra 1993. 
godine povodom 125-godišnjice Narodnog pozorišta, edited by Ana Matović, Nadežda Mosusova, Ranko Ivančević, 5-37. Belgrade: Muzikološki institut SANU, 1995. [Orig. in Serbian Cyrillic]

Nenezić, Zoran D. Masoni u Jugoslaviji 1764-1980. Belgrade: Narodna knjiga, 1984.

Pavlović, Mirka. "Veličina iz Beograda Bahrija Nuri Hadžić (1904-1993).” In 125 godina Narodnog pozorišta u Beogradu. Zbornik radova sa naučnog skupa održanog 16-19. novembra 1994, edited by Stanojlo Rajičić, 417-437. Belgrade: SANU, 1997. [Orig. in Serbian Cyrillic]

Pejović, Roksanda. Opera i balet Narodnog pozorišta u Beogradu (1882-1941). Belgrade, 1996. [Orig. in Serbian Cyrillic]

Radovanović, Aleksandar. Pregled istorije Narodnog pozorišta u Beogradu 1868-1993. Belgrade: Narodno pozorište, Institut za književnost i umetnost, 1994.
Švarc, Rikard. "Muzika u zemlji. Beograd. (Orguljski concert Jurija Arbatskog. Amaterski orkestar Lira. Jevrejsko vokalno udruženje Hanigun. Glasbena matica iz Ljubljane)." Zvuk 6 (1934): 233-234.

Švarc, Rikard. "Muzika u zemlji." Zvuk 8-9 (1935): 319-321.

Vasić, Aleksandar. "Muzički kritičar Rikard Švarc." Zbornik Matice srpske za scenske umetnosti i muziku 61 (2019): 87-103. [Orig. in Serbian Cyrillic]

Vinaver, Stanislav. "Muzički život." Misao 5-6 (1921): 416-424. [Orig. in Serbian Cyrillic]

Vučetić-Mladenović, Radina. Evropa na Kalemegdanu: "Cvijeta Zuzorić" i kulturni život Beograda 1918-1941. Belgrade: Institut za noviju istoriju Srbije, 2003. [Orig. in Serbian Cyrillic] 